\title{
LAUREATS DU CONCOURS DES MONTAGES SCIENTIFIQUES CONGRES ANNUEL 1979
}

\section{SCIENTIFIC EXHIBIT PRIZES ANNUAL MEETING 1979}

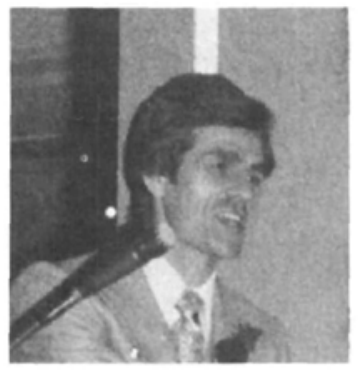

DR G. H. MORTON

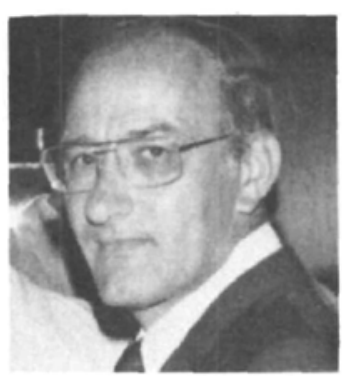

Dr D.J. STEWARD

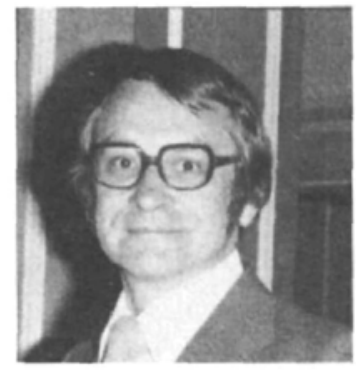

DR D.H. REIMER
Prizes were awarded on the occasion of The Annual Dinner of the Society for the three Scientific Exhibits judged to be the best presented at the Annual Meeting in Edmonton. June 17-20, 1979. The winners were: First prize, Dr. G.H. Morton, University of Alberta, "Fiberoptics and The Difficult Intubation"; Second Prize, Dr. D.J. Steward, Hospital For Sick Children, Toronto, "An Inexpensive Home Computer and the Anaesthetic Department"; Third Prize, Dr. D.H. Reimer, Health Sciences Centre. Winnipeg, "Anaesthetic Equipment Hazards".
Lors du diner annuel, on a attribué les prix du concours aux créateurs des meilleurs montages scientifiques exposés à Edmonton lors du congrès annuel de juin 1979. Premier Prix: Docteur G.H. Morton, Université d'Alberta: "La fibre optique les intubations difficiles". Deuxième Prix: Docteur D.J. Steward, Hôpital pour Enfants Malades de Toronto: "Un ordinateur domestique à prix abordable au service du département d'anesthésie." Troisième Prix: Docteur D.H. Reimer, Health Sciences Centre, Winnipeg: "Les guet-apens de l'appareillage d'anesthésie." 